\title{
BRIDGING THE GAP BETWEEN TOURISM VOCATIONAL EDUCATION AND EMPLOYMENT PRACTICE IN CROATIA: A VOCATIONAL TEACHERS' PERSPECTIVE
}

\author{
Oliver Kesar \\ Danijela Ferjanić Hodak \\ Ema Roginić
}

https://doi.org//10.20867/tosee.06.27

\begin{abstract}
Purpose - The main purpose of this research was to analyze the position of vocational education in Croatia from the perspective of tourism high school teaching staff. The main objective was to propose state regulations to limit the access of non-professionals to specialized jobs in tourism, and to enhance the status of tourism vocational education.

Methodology - Desk research was focused on the analysis of available body of knowledge related to tourism employment and tourism education. A structured questionnaire was used to collect primary data. The research sample included 104 tourism high school vocational teachers in Croatia. Descriptive statistics were used for data evaluation.

Findings - Although Croatia heavily relies on the economic benefits from tourism, its performance is often diminished due to a labor market mismatch in terms of specialization, knowledge and skills. This research determined that Croatia has a well-established and prospective high school education system for tourism, but lacks of image among employers and young generations. The state market regulation of tourism employment and the improvement of 'dual education system' of tourism education were strongly supported by respondents.

Contribution - The theoretical contribution of this research is to determine long-term gaps in matching tourism education outcomes and tourism employment practices. Empirical contribution is derived from the analysis of attitudes and perception of tourism high school teaching staff on how to improve tourism education and employment practice. Practical contribution is in providing empirically proved policy recommendations, while social contribution can be recognized in promoting tourism vocational education and professionalism to young generations.

Keywords: tourism, vocational education, employment practice, labor market regulation, Croatia.
\end{abstract}

\section{INTRODUCTION}

The appropriate education and training, as well as professional skills and work experience, are commonly accepted as the key formal characteristics of a job candidate that are checked and evaluated in the preselection stage of an employment process. There are, of course, many other personal characteristics (or personality traits), which are also important for the assessment of a candidate for particular job (e.g. responsible, loyal, honest, passionate, ambitious, adjustable, etc.), but those characteristics are usually evaluated during the interview and related to candidate's personal motivation to apply for a particular job. In the background of this research, above mentioned formal characteristics were observed as the outcome of formal education process, usually regarded as personal competitive advantages during the employment process. However, 
ToSEE - Tourism in Southern and Eastern Europe, Vol. 6, pp. 405-423, 2021.

O. Kesar, D. Ferjanić Hodak, E. Roginić: BRIDGING THE GAP BETWEEN TOURISM VOCATIONAL ...

job providers in tourism still widely support the employment of non-professionals in order to have wider choice of workers, speed up the hiring process, and keep the total labor costs low. Therefore, the main purpose of this paper was to analyse the role and current position of vocational high school education in Croatia from the perspective of tourism-oriented high school teaching staff. Two main objectives of this research were: (i) to discuss the necessity of introducing tourism labour market regulation in order to limit the access of non-professionals to highly professional workplaces in tourism, and (ii) to improve the status of tourism vocational education system in Croatia.

From the practical point of view, this research aimed to provide some policy recommendations that would go in favor of hiring professionals in tourism, particularly on job positions where employees are in direct contact with customers. That would be a significant qualitative improvement in a form of '4-win model' in which: 1) the educational system would fulfill its mission in the society; 2) service providers would utilize their full market potentials; 3 ) educated and skilled professionals would get the job they were educated for; and 4) customers would be able to experience the highest quality of tourism services at the time. In order to find out if such tourism labor market improvements are realistic and achievable in practice, various research methods were applied. As a case study in this research, Croatia was used due to its high level of economic dependence on tourism and strategic orientation towards quality-based market differentiation from its European competitors.

This paper is organized in four main sections. The first section is focused on theoretical background related to the significance of tourism employment for national economies, and tourism-related vocational education system in Croatia. The second section briefly presents the methodology used in this research. The third section brings synthesized research results and findings, while the fourth section provides some policy recommendations for the improvement of tourism vocational education in Croatia. The last section sets out the most important conclusions of the research.

\section{THEORETICAL BACKGROUND}

The importance of the human resources is particularly emphasized by the service sector due to multilayered process of the service delivery in which human work is irreplaceable to a large extent. "The story of successful tourism enterprises is one that is largely about people - how they are recruited, how they are managed, how they are trained and educated, how they are valued and rewarded, and how they are supported through a process of continuous learning and career development" (Fáilte Ireland 2005, 8). In spite of the ongoing debate on the replacement of human workforce by artificial intelligence and robotics technology (Drexler and Lapre 2019; Li, Bonn and Ye, 2019; McCartney and McCartney 2020), the quality of human work will remain the key asset in tourism for a very long time ahead. The reason for this is because the "impacts of staff-customer interaction cannot be defined and measured in material terms" (Lee-Ross and Pryce 2010,6). Technological development does not result with reduction in the number of employees in tourism, but greatly affects the employment structure, leads to the abolition of certain jobs and the emergence of new ones (Baum 2007, 1391). 
ToSEE - Tourism in Southern and Eastern Europe, Vol. 6, pp. 405-423, 2021.

O. Kesar, D. Ferjanić Hodak, E. Roginić: BRIDGING THE GAP BETWEEN TOURISM VOCATIONAL ...

\subsection{The significance of tourism employment for national economies}

Given that tourism is characterized, by its nature, as a predominantly a labor-intensive set of economic activities, the employment of large number of people has been widely recognized as one of its main contributions to the economy and the society. Nevertheless, tourism supports a diverse and versatile labor market characterized by two primary types of employment - direct and indirect. A direct employment in tourism refers to jobs in its core economic activities like tourist attractions, hotels, travel agencies etc., while indirect employment includes jobs in all economic activities that logistically support the supplyside of tourism, such as food production, utility services, interior design, etc. Another approach to tourism-related employment differentiate full-time job from part-time and seasonal jobs, the latter two types being targeted at vocational trainees and students. Regardless of the type of employment, the workforce represents the key asset of all tourism businesses, particularly of those directly involved in service delivery, because the quality of service directly influences customer's level of satisfaction, consumption and loyalty. This is consistent with the findings of Sobaih $(2015,221)$, who reported that the competitive advantage of a tourism service provider directly depends on the "availability of quality workers to deliver, operate and manage its products and services".

According to Liu and Wall $(2006,159)$, tourism employment is often used as a tool for boosting economic growth and development. The capacity to significantly improve local economy and the standard of living for residents, is one of its main advantages, which is applicable to both, developed and emerging economies. This observation is in line with two previously published studies. The first study refers to Bečić and Črnjar $(2009,206)$ who argue that "in many countries, tourism boosts new jobs and contributes to wellbeing of the local community", while the second one refers to Moutinho $(2005,254)$ who emphasized that "tourism is responsible for vast majority of jobs, and therefore affects both developed and undeveloped countries". The importance and intensity of tourism employment for national economy are mostly determined by five key factors: 1) geographic position, 2) the size of country, 3) total population, 4) level of development, and 5) the extent to which economy is dependent on tourism (measured by the contribution of tourism to national GDP). According to Tasci and Knutson (2004, 98), "the development stage of a country is inversely related to the level of its dependence on tourism". If it is highly developed, it would have diverse industries in its economic structure, rather than being highly dependent on tourism. On the other hand, the less developed country is, the greater the impact of tourism would be on national economy.

As a developing country in the Mediterranean region, Croatia heavily relies on economic benefits from tourism, namely income, employment and well-being. According to Tourism Satellite Account 2016 report published by the Croatian Bureau of Statistics, direct contribution of tourism to national GDP amounted to 5.34 billion euros or $11.4 \%$ (CBS 2019). Since the World Travel and Tourism Council considers direct, indirect and induced impacts when assessing the size of tourism contribution to the national economy, the total travel and tourism contribution to Croatia's GDP was estimated to 25\% (WTTC 2020). In pre-pandemic 2019, the national statistics office of Croatia has recorded a total of 19.6 million tourist arrivals, who spent 91.2 million overnights in commercial type of accommodation facilities. Among these figures, international demand accounted for $88.7 \%$ in arrivals, and $92.2 \%$ in overnights (CBS 2020). In 2019, the WTTC also reported that the 
ToSEE - Tourism in Southern and Eastern Europe, Vol. 6, pp. 405-423, 2021.

O. Kesar, D. Ferjanić Hodak, E. Roginić: BRIDGING THE GAP BETWEEN TOURISM VOCATIONAL ...

proportion of tourism employment in total employment in Croatia was estimated to $25.1 \%$ (or 383,400 employees). It means that, every fourth employee in Croatia was directly or indirectly employed in tourism. However, the importance of recruiting quality human resources in tourism is largely neglected by tourism employers in Croatia. In the conclusion remarks of the study on the educational system of tourism experts, Bartoluci and Budimski (2010) clearly stated that "a large proportion of the inadequately educated workforce continuously work in Croatian tourism". Since the workforce is the key resource in tourism, its quality in terms of education and adopted skills, has a direct reflection on the quality of overall tourism offer.

Although tourism employment provides work opportunities for many full-time, part-time and seasonal job-seekers, Riley and Szivas (2009) emphasize that the vast majority of these jobs are still of low-skilled, low-paid and taken over by non-professional workers whose formal education, experience and skills are often inadequate. For that reason, the success of tourism is often diminished due to labor market mismatch in terms of specialization, knowledge and skills. Therefore, the education has become increasingly important, as a valuable starting point for the development of human capital (Ladkin 2005).

\subsection{Tourism-related vocational high school education in Croatia}

In Croatia, the vocational high school system for tourism provides basically two types of programs: 3-year programs for three catering profiles (Chef, Waiter, and Confectioner) and 4-year programs for four tourism profiles (Hotel and Tourism Technician, Tourism and Hotel Commercialist, Agro-Tourism Technician, and Experimental Program of Tourism Gymnasium). Except for the Tourism Gymnasium program, all other vocational programs allow the acquisition of a vocation title, which enable students a recognizable position on the tourism labor market. For high school students who want to upgrade their formal education in tourism at the university level, students must complete a 4-year high school program and pass the State Matura exam.

According to statistical data for school year 2020/2021, provided by the Ministry of Science and Education of the Republic of Croatia (MSE 2021), the number of high school students was in total 458,248, enrolled in total of 1,306 schools. Surprisingly, 4-years vocational high school programs were chosen by only 63,937 students (14\% of total), while in 4-year vocational high school programs for tourism (VPTs) 8,297 students ( $1.8 \%$ of total) were enrolled (Table 1$)$. In overall number of students enrolled into 4 year VPTs, $66.1 \%$ of them were female. 
ToSEE - Tourism in Southern and Eastern Europe, Vol. 6, pp. 405-423, 2021. O. Kesar, D. Ferjanić Hodak, E. Roginić: BRIDGING THE GAP BETWEEN TOURISM VOCATIONAL ...

Table 1: Vocational high schools for tourism and students in Croatia, 2013-2020

\begin{tabular}{cccc}
\hline School Year & $\begin{array}{c}\text { Schools with 4-year } \\
\text { VPT }\end{array}$ & $\begin{array}{c}\text { Students enrolled } \\
\text { into 4-year } \\
\text { VPT (all classes) }\end{array}$ & $\begin{array}{c}\text { Students enrolled } \\
\text { into 4-year VPT } \\
\text { (final classes) }\end{array}$ \\
\hline $2013 / 2014$ & 76 & 9,279 & 2,106 \\
$2014 / 2015$ & 76 & 9,402 & 2,373 \\
$2015 / 2016$ & 76 & 9,139 & 2,385 \\
$2016 / 2017$ & 74 & 8,801 & 2,393 \\
$2017 / 2018$ & 74 & 8,503 & 2,267 \\
$2018 / 2019$ & 74 & 8,436 & 2,166 \\
$2019 / 2020$ & 74 & 8,237 & 2,020 \\
$2020 / 2021$ & 75 & 8,297 & 2,163 \\
\hline
\end{tabular}

Source: MSE 2021

As seen in Table 1, in school year 2020/2021, the 4-year VPTs were delivered in 75 vocational high schools (5.7\% of total). Considering the geographical distribution of high schools that offer VPTs, it is evident that they are evenly spread throughout the country - 38 schools were located in the continental part (with 4,081 students or $49.2 \%$ of total), while the rest of 37 schools were along the coastal part of Croatia (with 4,216 students or $50.8 \%$ of total). It is valuable to mention that 8 schools are located on the Croatian islands, with 582 students (7\% of total 4-year VPT students). In total, high schools that VPTs are located in 59 cities/towns or municipalities. Analyzed by ownership type, 71 high schools with 4-year VPT are public schools (97.3\% of total VPT students), while 4 high schools are privately owned and financed (2.7\% of total VPT students).

As of data in Table 2, in school year 2020/2021, the most popular 4-year VPTs in Croatia were: 1) the Hotel and Tourism Technician (HTT) program with $61.3 \%$ of high school students enrolled in VPTs, 2) the Tourism and Hotel Commercialist (THC) program with 27.6\%, 3) the Agro-Tourism Technician (ATT) program with 8,8\%, and 4) the Experimental Program of Tourism Gymnasium (EPTG) program with relatively modest share of $2.3 \%$ of students enrolled in VPTs.

Table 2: Four-year vocational high school programs for tourism and enrolled students in Croatia, 2013-2020

\begin{tabular}{ccccc}
\hline School Year & HTT & THC & ATT & EPTG \\
\hline $2013 / 2014$ & 5,565 & 2,622 & 919 & 173 \\
$2014 / 2015$ & 5,451 & 2,683 & 971 & 297 \\
$2015 / 2016$ & 5,262 & 2,569 & 938 & 370 \\
$2016 / 2017$ & 5,133 & 2,432 & 827 & 409 \\
$2017 / 2018$ & 4,997 & 2,307 & 843 & 356 \\
$2018 / 2019$ & 5,028 & 2,286 & 790 & 332 \\
$2019 / 2020$ & 5,038 & 2,200 & 734 & 265 \\
$2020 / 2021$ & 5,088 & 2,289 & 729 & 191 \\
\hline
\end{tabular}

Source: MSE 2021

According to the Ministry of Science and Education (MSE, 2021), it is evident that between 2013 and 2020, the number of enrolled students into all high school programs 
ToSEE - Tourism in Southern and Eastern Europe, Vol. 6, pp. 405-423, 2021.

O. Kesar, D. Ferjanić Hodak, E. Roginić: BRIDGING THE GAP BETWEEN TOURISM VOCATIONAL ...

in Croatia has decreased by $10 \%$, while the interest for the 4 -year VPTs dropped for $10.6 \%$. Data clearly indicates that the decrease in number of students enrolled in 4-year VPTs is the consequence of decrease in total number of students, not the decrease of interest for tourism vocational education itself.

Apart from the quantity aspects of tourism-related high school education, its quality is also important aspect in educating future tourism professionals. Generally, the vocational education for tourism has been considered as quite complex, primarily due to the complexity of tourism system, but also because of the frequent and unpredictable changes in market trends. Therefore, it is necessary to make education for tourism flexible according to major market trends and to prepare students for their careers in the most effective way. To achieve this goal, tourism vocational high schools have to make strong efforts in two different, but interrelated ways. The first one is focused on upgrading VPTs curricula, while the other is focused on cooperation with business sector in order to establish efficient internship schemes for their students. This two-way approach supports so called 'dual education system' of tourism education, particularly developed in Germany and Netherlands (Liu and Xu 2017; Richards 2003; Peršić 1998). Considering the fact that service providing requires possession of special competences and skills, they must be acquired and trained during the vocational education. There are many tourism-specific competences and skills that are regularly transferred to students as a direct know-how, incorporated in 4-year VPTs curricula. In the process of applying for a job, these competences and skills are usually required qualifications for various work positions, such as $\mathrm{F} \& \mathrm{~B}$ service manager, tour guide, event organizer, tourism product developer, etc. (Shereni 2019). In that sense, the market matching can be achieved only by implementing competency-based education model which diminishes disparities between students' (as future employees') competences and job requirements (Silitonga 2020). Development and implementation of such vocational education-forbusiness model is a complex and long-lasting process, but it provides best possible results in ensuring high quality workforce in tourism.

As Vizjak and Vizjak (2015) stated, current teaching methods used in tourism education are dominantly an expression of present labor market needs, and are not opened for the close future. According to same authors, characteristics like the inertia of curricula and bureaucratized teaching, result in leaving the school burdened with a large amount of obsolete information and knowledge that does not benefit them in future jobs. When it comes to teaching methods, they can be divided into two main groups: 1) classical which include: narration, dialogue method, discussion method, lecture, method of written and graphic production, the case study method, the laboratory method, etc.; 2) recent which include: experiential learning, action teaching, brainstorming, brainwriting, method 635, etc. (Starc, Rodica and Konda 2015). Recent teaching methods should be combined with classical methods in order to involve students in learning process and to teach them to think more and solve actual challenges which can occur in practice.

In the context of education, innovation can be regarded as "dynamic changes that add value to the educational process in order to obtain measurable results in terms of satisfaction of the interested parties or academic performance" (OECD 2010). This process is largely dependent on decision makers and curricula creators. According to the research taken by Hidalgo-Peñate et al. (2020), the innovativeness can also be improved through the affective 
ToSEE - Tourism in Southern and Eastern Europe, Vol. 6, pp. 405-423, 2021.

O. Kesar, D. Ferjanić Hodak, E. Roginić: BRIDGING THE GAP BETWEEN TOURISM VOCATIONAL ...

commitment of the teaching staff and that the existence of emotional attachment to the school favors innovation, through the staff's greater dedication, effort, and willingness to contribute new ideas and exchange knowledge. Therefore, it is not questionable whether or not teachers have ideas to innovate the VPTs and implement new methods. The real question is - do they have a clear perception of how to initiate changes? This is one among other questions raised and implemented in the primary research of this study whose main goal was to analyze the role and current position of tourism high school vocational education in Croatia from the perspective of a teaching staff.

\section{METHODOLOGY AND DATA COLLECTION}

\subsection{Methodological approach}

This research was conducted in order to reveal the attitudes and perception of 4-year vocational tourism-oriented high school teachers in order to improve tourism education, increase its popularity among younger generations, fill the gap between the outcomes of 4year VPTs and tourism employment practice, and to suggest some policy recommendations for tourism labor market regulation in Croatia. The online survey method was used for data collection, as the most convenient way of reaching respondents during the pandemic times. Desk research was based on the analysis of available scientific and practical knowledge on various aspects of the internal and external perception of tourism education system and employment practices.

\subsection{Data Collection Techniques}

The empirical research was based on a self-administered questionnaire distributed among the high school teachers of tourism related subjects within 4-year VPTs in Croatia. The questionnaire contained 31 questions, both closed-ended and open-ended, organized in three sections. The aim of the first section was to analyze teachers' personal profiles and their background, which involved demographics, education, job experience, position and affiliation. The second section aimed to analyze teachers' perception of 4-year VPTs in order to better understand the status of currently available 4-year VPTs and the opportunities for their improvement. The third section was about revealing teachers' attitudes on upgrading the vocational education system for tourism and related labor market regulation. The main point of the latter section was to reveal teachers' opinions of how to improve the education system for tourism, enhance tourism labor market matching, and finally, to increase the quality of overall tourism service provision in Croatia.

At the end of February 2021, prior to final distribution, the questionnaire was sent to the group of selected high school teachers with longest working experience and a great knowledge of tourism vocational education system in Croatia, for a check and pretesting. Some minor corrections had to be done. The final version of questionnaire was distributed online to all vocational high schools in Croatia that provide 4-year VPTs. The period of data collection spanned March to April 2021. The survey was completely anonymous and voluntary. 
ToSEE - Tourism in Southern and Eastern Europe, Vol. 6, pp. 405-423, 2021.

O. Kesar, D. Ferjanić Hodak, E. Roginić: BRIDGING THE GAP BETWEEN TOURISM VOCATIONAL ...

\subsection{Sample and data analysis}

The statistical population in this research was constructed exclusively out of vocational high school teachers who primarily teach tourism-related subjects within the framework of 4-year VPTs in Croatia. The research was based on the national-level sample as the survey was distributed to all the public vocational high schools that offer 4-year VPTs. As shown in Table 1, during the sampling for this research, there were 75 of them (MSE 2021). According to Croatia's Agency for Vocational Education and Training and Adult Education (further on as Agency for vocational education) internal database, the total population of such teachers in Croatia is not much larger than 200. The main constraint in determining the exact number of teachers was the fact that some of them were only partly engaged in 4-year VPTs. The final sample was composed of 104 teachers from all Croatia's regions, which accounts for approx. 50\% of the total population that teach tourism at the high school education level. Such large share of respondents in total population ensures that the findings and conclusions in this research can be regarded as accurate and reliable. Once the survey was completed, the data were analyzed using simple descriptive statistical methods.

\section{RESEARCH FINDINGS AND DISCUSSION}

Given that Croatian economy is heavily dependent on tourism and its economic performance (Mandić et al. 2018; Šuligoj 2017; Pavlić et al. 2015), it was reasonable to analyze gaps in tourism labor market matching and to discuss issues related to tourism vocational education in order to ensure qualified and reliable work force for tourism. Croatia has well developed and geographically well distributed network of vocational high schools that offer one or more VPTs.

Based on sample data from high school teachers engaged in 4-year VPTs, the primary research revealed that $73.1 \%$ of teachers were female. The average age of respondents was 47 , but there was $8.7 \%$ of respondents who were of age 60 or older. The sample respondents have on average 21.6 years of work experience in general, while the average number of years of working as a high school teacher was 15.4. Also, it is interesting to emphasize that the mod value of teaching tourism-oriented subjects was 20 years. About $40 \%$ of respondents have completed their high school education in tourism and hospitality, while other respondents completed the economics program $(25 \%)$, the gymnasium program $(25 \%)$ or other vocational high school program $(10 \%)$. Such educational background structure can be regarded as inadequate, particularly in case of younger teachers who haven't specialized tourism during their high school and/or university level of formal education, but they are expected to achieve excellent results in tourism-specialized teaching process. Simultaneously with the teaching process in which they already participate, teachers with other formal education backgrounds need to acquire a complex tourism-related knowledge and practice, which can be quite difficult and demotivating for them. In line with that, Tomljenović and Čorak (2012) argue that "without a continuous education of vocational teachers, their professional development depends on their personal motivation". In order to counteract this issue, the introduction of the licensing scheme for teachers would improve the quality of teaching staff, education process and learning outcomes. Such licensing scheme should impose the 
ToSEE - Tourism in Southern and Eastern Europe, Vol. 6, pp. 405-423, 2021.

O. Kesar, D. Ferjanić Hodak, E. Roginić: BRIDGING THE GAP BETWEEN TOURISM VOCATIONAL ...

unconditional requirement of possessing formal tourism education to be able to teach tourism-related subjects, followed by continuous education and opportunities for subspecialization. According to Guskey (2002), such standards are needed to support the evaluation and better development of their teaching profession.

The majority of respondents were involved in the THC program (59.6\%), while the second most frequent engagement was in the HTT program (48.1\%). It is worth to notice that almost $50 \%$ of respondents are teaching two or more tourism-related subjects in one or both above mentioned VPTs.

\subsection{Teachers' perception of 4-year vocational programs for tourism}

Considering trends in tourism-related high school education during the past five years, about $46 \%$ of the respondents noticed moderately or significantly growth of the general interest of high school students in enrolling 4-year VPTs, while $37 \%$ consider that there were no changes in student interest over the past five years. While enrolling the VPT, students prefer THC (46\%) and HTT (44\%) programs. More than half of the respondents $(52.5 \%)$ agreed that the specialization of 4-year VPTs should be introduced according to special interest tourism (e.g. cultural, business, health, etc.), while $47.4 \%$ thought there should be specialization according to business functions (e.g. marketing, procurement, finance, staffing, controlling, etc.). These findings are consistent with the previous results obtained by Tomljenović and Črak (2012) in which respondents highlighted "the insufficient modularity" of VPTs in Croatia that makes impossible for students to adapt to the dynamics of labor market needs and regional peculiarities. Therefore, as stated by Lo (2005), to meet the professional skills requirements of contemporary tourism market needs, tourism education should be tailored.

When it came to programs specialized according to level of operational management (enterprise, destination, region, national level), respondents in this research had quite different opinions. One third of respondents thought this should be adopted, other third thought the opposite and the rest of respondents $(47.4 \%)$ were not sure about that. It is valuable to notice that the specialization of VPTs are increasingly supported by older and experienced teachers, while younger teachers are increasingly unsure about that as their age and work experience is getting lower. Although they consider the introduction of specialized programs in tourism as a good idea, teachers were not sure whether the education system has sufficient capacities to implement such changes or not. In fact, only a quarter of them are certain that such conditions exist.

Unsurprisingly, $46.2 \%$ of respondents, particularly older and with more work experience in teaching tourism subjects, found currently available 4-year VPTs more or less incompatible to the contemporary needs of the labor market, while $32.7 \%$ of teachers considered them more or less compatible. The Figure 1 shows the average grades of respondents measured with 5-point Likert scale on the importance of a particular way of connecting schools and employers in order to improve 4-year tourism programs. 
ToSEE - Tourism in Southern and Eastern Europe, Vol. 6, pp. 405-423, 2021.

O. Kesar, D. Ferjanić Hodak, E. Roginić: BRIDGING THE GAP BETWEEN TOURISM VOCATIONAL ...

Figure 1: The importance of connecting schools and employers in order to improve 4-year vocational programs for tourism

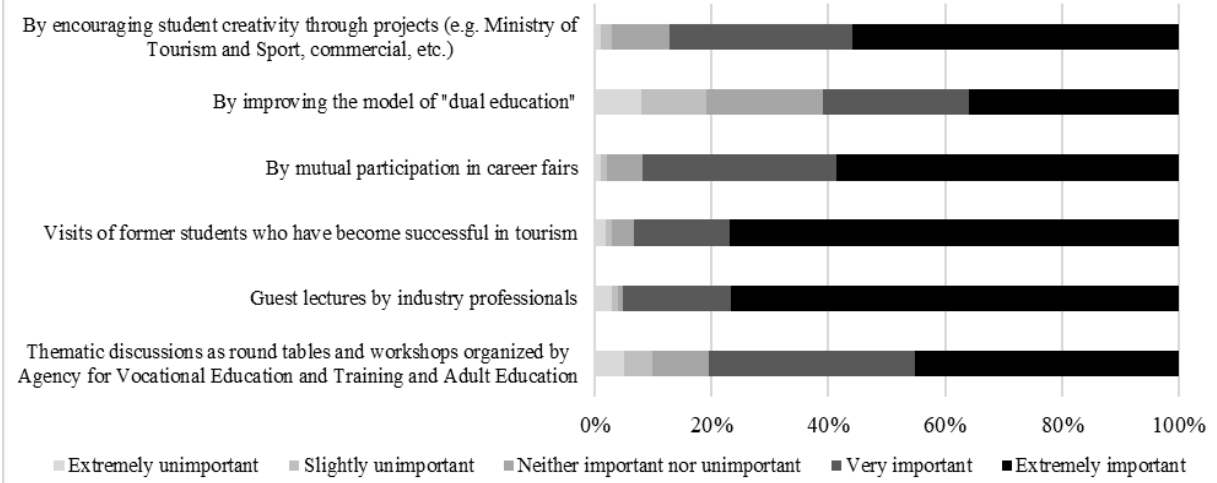

Source: Survey data

Each item in this question was evaluated using a five-point Likert scale where 1 represented "extremely unimportant" and 5 represented "extremely important". Cronbach's Alpha for this set of items was 0.85 , indicated strong test reliability.

Table 3: The importance of cooperation between schools and employers in order to improve 4-year vocational programs for tourism, $\mathrm{N}=104$

\begin{tabular}{|c|c|c|c|}
\hline \multicolumn{2}{|c|}{ Variable } & \multirow{2}{*}{$\frac{M}{4.09}$} & \multirow{2}{*}{$\frac{\mathrm{SD}}{1.12}$} \\
\hline 1) & $\begin{array}{l}\text { Thematic discussions as round tables and workshops organized by } \\
\text { Agency for vocational education }\end{array}$ & & \\
\hline 2) & Guest lectures by industry professionals & 4.65 & 0.81 \\
\hline 3) & Visit of former students who have become successful in tourism & 4.65 & 0.77 \\
\hline 4) & By mutual participation in career fairs & 4.46 & 0.81 \\
\hline 5) & By improving the model of 'dual education' & 3.67 & 1.33 \\
\hline 6) & $\begin{array}{l}\text { By encouraging student creativity through projects (e.g. Ministry of } \\
\text { Tourism and Sports, commercial etc.) }\end{array}$ & 4.37 & 0.88 \\
\hline
\end{tabular}

Note: $\mathrm{M}=$ mean, $\mathrm{SD}=$ standard deviation; Variable scale: from 1 to 5

It is evident that the majority of respondents consider most of the aspects of cooperation either very or extremely important. As many as $76.7 \%$ of respondents believed that inviting tourism professionals as guest lectures is extremely important, while about the same share of them considered former students could also give their contribution to the improvement of 4-year VPTs. Career fairs and project engagements were also important media in connecting high school students and employers.

The following Figure 2 shows the respondents' assessment on the importance of school's communication with other stakeholders related to the improvement of 4-year VPTs. 
ToSEE - Tourism in Southern and Eastern Europe, Vol. 6, pp. 405-423, 2021.

O. Kesar, D. Ferjanić Hodak, E. Roginić: BRIDGING THE GAP BETWEEN TOURISM VOCATIONAL ...

Figure 2: The importance of the communication between school and stakeholders

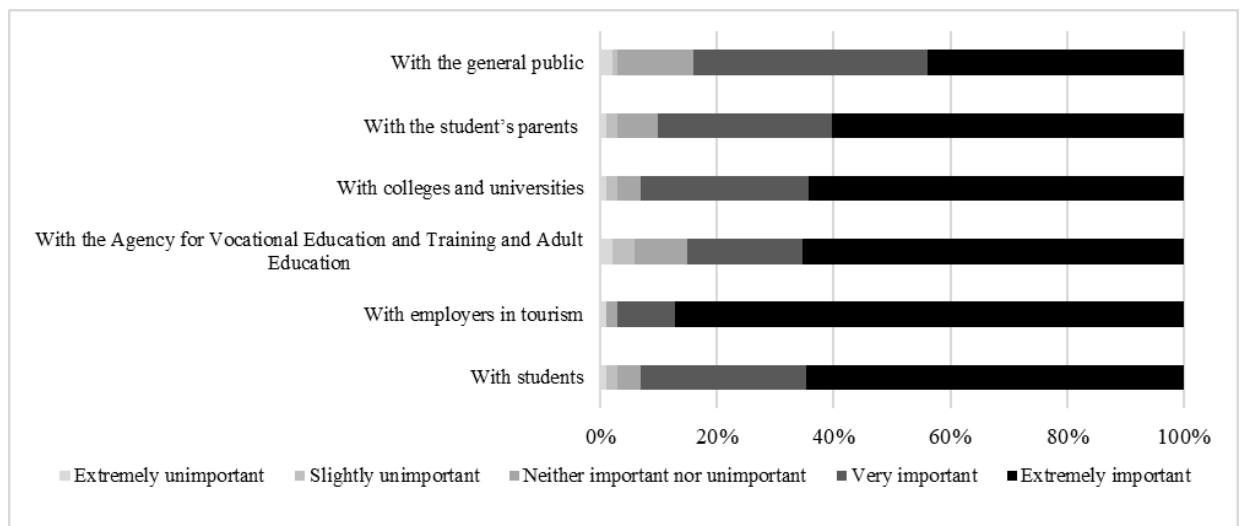

Source: Survey data

Each item in this question was also evaluated using a five-point Likert scale where 1 represented "extremely unimportant" and 5 represented "extremely important". The calculated Cronbach's Alpha for this set of items was 0.90, indicated strong test reliability.

Table 4: The importance of the communication between school and stakeholders, $\mathrm{N}=104$

\begin{tabular}{lcc}
\hline Variable & $\mathrm{M}$ & $\mathrm{SD}$ \\
\hline 1) With students & 4.51 & 0.78 \\
2) With employers in tourism & 4.76 & 0.66 \\
3) With the Agency for vocational education & 4.40 & 0.96 \\
4) With colleges and universities & 4.51 & 0.78 \\
5) With the students' parents & 4.41 & 0.84 \\
6) With the general public & 4.15 & 0.94 \\
\hline
\end{tabular}

Note: $\mathrm{M}=$ mean, $\mathrm{SD}=$ standard deviation; Variable scale: from 1 to 5

More than $60 \%$ of teachers agreed that the communication with employers in tourism, current and future students, their parents, the Agency for vocational education as well as with colleges and universities, is extremely important. However, analyzing the importance of communication with the general public, in terms of running promotional campaign highlighting to the content, values and advantages of completing VPT, it can be seen that $44 \%$ of respondents consider it extremely important, while another $40 \%$ as very important. That is in line with the fact that the general public awareness and perception of the quality of vocational education system for tourism seems to be critical for image creation and the improvement of the status of such schools in the society. However, the large proportion of teachers who don't consider this communication as extremely important implies that drawing attention of the general public in this regard should be focused, well-organized, attractively designed and cost-effective. 
ToSEE - Tourism in Southern and Eastern Europe, Vol. 6, pp. 405-423, 2021.

O. Kesar, D. Ferjanić Hodak, E. Roginić: BRIDGING THE GAP BETWEEN TOURISM VOCATIONAL ...

Asked to assess their position for initiating innovations of the VPTs, the majority of teachers $(55.9 \%)$ found it difficult to assess whether they have or not the power to initiate any changes. On average, female teachers were slightly less confident in their power to initiate changes, than their male colleagues. About $17 \%$ of respondents with many years of teaching and practical experience in tourism are familiar with curriculum innovation process as they participated directly or indirectly in such activities. Some of the respondents stressed that they did not participate in curriculum innovation activities because they were aware of the length of the process, which is quite disappointing. Another mentioned issue in this regard was that individual suggestions were generally ignored. They also emphasized issues such as centralization of education system and the lack of communication and coordination. According to respondents, those in charge of making decisions are very slow and with difficulty accept any suggestion. Hence, they conclude that there is generally a lack of real interest from relevant public institutions to introduce changes, which additionally reduces the trust in institutions. Clearly, they are open to changes and innovations as $69.3 \%$ of respondents claimed that they are using modern IT technology relatively or very much in teaching process.

Almost half of the teachers $(48.5 \%)$ participating in the survey considered that a detailed revision and innovation of 4-year VPTs should be implemented according to the changes in the labor market and not at strictly defined intervals. The proportion of $30.7 \%$ of teachers thought that the optimal time span for changes should be every 5 years, while another $19.8 \%$ consider a 10 year-interval more suitable. It is also worth noticing that the teachers with 15 or less years of experience are more flexible in introducing changes in VPTs curricula. Asked to assess how strong was the 'focus on future labor market needs' during the innovation process of 4-year VPTs, $51.5 \%$ of the participants consider that aspect poor or very poor, while only $16.4 \%$ of teachers consider it strong or very strong.

\subsection{Teachers' attitudes towards the tourism education system and labor market regulation}

According to teachers' experience related to the tourism employment practices in Croatia, the majority of them consider tourism-related jobs very $(39.6 \%)$ or relatively exposed $(31.7 \%)$ to those without formal education in tourism. In order to reduce such exposure, $88 \%$ of teachers agreed that the state authorities should formally regulate tourism labor market, namely the employment process, by introducing formal criteria according to which someone could or could not apply for a particular tourism-related job. Unlikely, $11.9 \%$ of respondents did not consider such regulation as a good policy, considering current liberal conditions as perfectly fine.

Those teachers, who supported the state regulation of tourism labor market, were further asked to assess the possible outcomes of such regulation. More than $95 \%$ of respondents partially or completely agreed that labor market regulation would make tourism-related professions more respected, while $94 \%$ of them that schools would increase their visibility within the high school educational system. A large proportion of $93 \%$ of teachers believe that vocational high schools would improve their status in society, especially among younger generations and increase their intention to enroll VPT. Interestingly, only $64 \%$ of 
ToSEE - Tourism in Southern and Eastern Europe, Vol. 6, pp. 405-423, 2021.

O. Kesar, D. Ferjanić Hodak, E. Roginić: BRIDGING THE GAP BETWEEN TOURISM VOCATIONAL ...

the respondents partly of completely agreed that state intervention in tourism employment process would bring better status to the teachers.

Figure 3: Teachers' attitudes towards labor market regulation in tourism

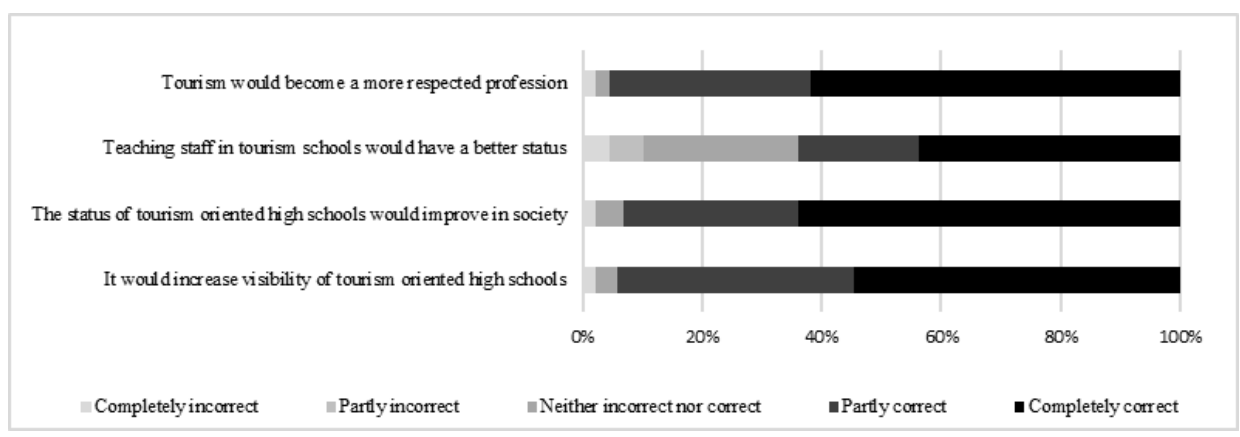

Source: Survey data

Also, in this question each item was evaluated using a five-point Likert scale where 1 represented "completely incorrect" and 5 represented "completely correct". For this set of items Cronbach's Alpha was 0.91, indicated strong test reliability.

Table 5: Teachers' attitudes towards labor market regulation in tourism, $\mathbf{N = 1 0 4}$

\begin{tabular}{lcc}
\hline Variable & M & SD \\
\hline 1) It would increase the visibility of tourism oriented high schools & 4.31 & 0.75 \\
2) The status of tourism oriented high schools would improve in society & 4.40 & 0.77 \\
3) Teaching staff in tourism schools would have a better status & 3.96 & 0.99 \\
4) Tourism would become a more respected profession & 4.40 & 0.75 \\
\hline
\end{tabular}

Note: $\mathrm{M}=$ mean, $\mathrm{SD}=$ standard deviation; Variable scale: from 1 to 5

Asked about their perception of the employment mediation in tourism, 57\% of respondents considered the system of employment mediation in tourism insufficiently developed and structured when it comes to the recognition of specialized job positions in tourism. Only $6.7 \%$ of respondents answered that such system is sufficiently developed.

When it came to the assessment of the extent to which 4-year VPTs provide students with appropriate knowledge for continuing their formal education in tourism studies at college or university level, 95\% of the teachers assess VPTs as satisfactory or completely satisfactory. However, teachers considered that students who completed their 4-year VPT will be better prepared for studies at the college level.

Finally, respondents were asked to express their views as well as to give some suggestions of how to improve the status of tourism high schools in society, and thus their personal status as a teacher in the eyes of the students, their parents and tourism employers. It was not surprising to reveal that teachers are facing similar challenges and coping with the same issues. Among the issues, the most frequent were: employment of low-payed and low- 
ToSEE - Tourism in Southern and Eastern Europe, Vol. 6, pp. 405-423, 2021.

O. Kesar, D. Ferjanić Hodak, E. Roginić: BRIDGING THE GAP BETWEEN TOURISM VOCATIONAL ...

skilled foreign workers, lack of practical experience of working in tourism among teachers, lack of motivation among tourism job providers to deal with students on internship program, bad image of jobs in tourism, a better reward system for teachers, excessive number of high schools that provide tourism programs, etc. Apart from the issues, teachers' suggestions for the improvement go in favor of more domestic and international competitions, real entrepreneurial activities, creative events and financially supported projects for students, but also to make schools' and students' achievements more visible to job providers and the general public. Finally, some most frequent aspects were used for shaping the policy recommendations presented in the next section.

\section{POLICY RECOMMENDATIONS}

Based on both, theoretical and empirical research findings, nine policy recommendations can be proposed to improve the vocational tourism high school education system and the employment practice in Croatia:

1) Curriculum innovations - The Agency for vocational education, tourism vocational high schools and a board of representatives of various tourism stakeholders (job providers, professional associations etc.) should work together and develop a more diverse portfolio of VPTs (modular curricula) according to special interest tourism niches (e.g. cultural, business, health, etc.) or business functions (e.g. tourism marketing, finance in tourism, HR in tourism, etc.). Researches done by Tomljenović and Črak $(2012,21)$ for Croatia and Wang et al. $(2010,11)$ for Australia, proved that the largest gap of perceptions between tourism-related teaching staff and tourism job providers appears to be in the structure and the importance of core study areas. Therefore, the collaboration among mentioned stakeholders is essential for innovations of VPTs curricula to become accepted and effective. Additionally, the representatives from relevant institutions of higher education for tourism could serve as an advisory board to provide curricula harmonization and guidelines for the improvement of vertical permeability between educational levels (high school-college-university). Curriculum innovations should include more practical work and development of entrepreneurial skills;

2) Internal environment - There is a constant need for the improvement of tourism vocational high school premises and equipment, as well as the organizational education and training for teachers. The latter implies the introduction of licensing scheme for vocational teachers based on lifelong education programs provided by national centers of competencies in tourism. As argued by Nurhadi et al. (2017), the policy on the quality of the future vocational teachers needs to be focused on the development of the certification process and on the establishment of competency standards of licensed vocational teachers;

3) Promotional campaign - State institutions, namely the Ministry of Tourism and Sports, Ministry of Science and Education and the Agency for vocational education, in cooperation with national centers of competencies in tourism, should develop and continuously run promotional campaign to make tourism-related vocational education and jobs more attractive to the future students and draw attention of job providers in 
ToSEE - Tourism in Southern and Eastern Europe, Vol. 6, pp. 405-423, 2021.

O. Kesar, D. Ferjanić Hodak, E. Roginić: BRIDGING THE GAP BETWEEN TOURISM VOCATIONAL ...

tourism to focus on professionals in recruiting process. This is in line with Perman and Mikinac $(2014,621)$ who stated that the weaker growth of students' interest in enrolling VPTs can be attributed to poor promotion of professional occupations and weak employment opportunities after graduating from tourism high school;

4) Status and image - Since the majority of jobs in tourism are generally poorly perceived, as low-skilled, low-paid and taken by non-professionals (Riley and Szivas 2009), a strong effort of the previously mentioned state institutions should be directed towards the improvement of the status and image of tourism vocational education, high schools and teachers, based on their intermediate position between tourism education system and labor market. A strong support in this endeavor should be provided by national centers of competencies in tourism;

5) Cooperation - The Agency for vocational education and tourism vocational high schools should intensify their efforts in establishing more tight cooperation with tourism job providers in order to be up-to-date with the contemporary tourism labor market requirements in terms of high level of professional skills, specialized know-how and customization. Better communication and cooperation would directly contribute to the improvement of the matching between demand and supply on tourism labor market. The previous study (Tomljenović and Črak 2012) revealed that tourism job providers do not completely understand the way of how tourism vocational education system works, do not have clearly defined internship plans for students and show a very low level of interest for cooperation with schools regarding their education as mentors. An improved understanding of how best to educate future tourism professionals "would bring benefits of both, individuals who wish to develop a career in tourism and the tourism industry as a whole" (Ladkin 2005, 447);

6) Employment mediation - Based on the formalized classification of direct and indirect job positions in tourism, the improvement of more diverse and precise job classification and description used by the Croatian Employment Service and employment agencies while offering vacancies, would increase the recognition and visibility of tourismrelated professions;

7) 'Dual education system' - The Agency for vocational education, tourism vocational high schools and tourism job providers should closely cooperate towards upgrading the 'dual education system' for tourism, including the internship, scholarship and grant programs for students, which would enable employers to attract future employees prior to their graduation. The previous research in this context (Tomljenović and Corak 2012), however, indicated that the key aspect of internship program is in quality mentoring system, but also in coordination between job supervisor and vocational teacher;

8) Professionalism - Since the quality of employees and the quality of service provision are closely interrelated, tourism job providers must be aware of the advantages of employing educated and skilled tourism professionals. To meet this goal, a continuous promotion of tourism education opportunities and diversity of tourism careers should be recognized as a primary source of skilled and formally educated tourism professionals (WTTC 2002); 
ToSEE - Tourism in Southern and Eastern Europe, Vol. 6, pp. 405-423, 2021.

O. Kesar, D. Ferjanić Hodak, E. Roginić: BRIDGING THE GAP BETWEEN TOURISM VOCATIONAL ...

9) Labor market regulation - Tourism vocational education system (high-schools, colleges and universities), tourism job providers, employment mediation agencies and the Croatian Bureau of Statistics should develop a list of highly profiled and most wanted jobs in tourism, particularly of those in direct service providing, and with state authorities, namely the Ministry of Labor, Pension System, Family and Social Policy, and the Croatian Employment Service, should introduce formal criteria according to which someone could or could not be employed on particular tourism-related job position.

\section{CONCLUSION}

Although Croatia heavily relies on the economic benefits from tourism, the vast majority of tourism jobs are still of low skilled, low paid and taken over by non-professional workers whose formal education, experience and skills are often inadequate. The gap between such mismatching employment practices and tourism education outcome is significant. This study revealed that Croatia has a well-established and prospective education system for tourism professionals, but lacks of public system support and image among employers and young generations choosing tourism-related study programs as their second best. The examined teaching staff in this research strongly agreed with the need for state tourism labor market regulation, because they believe that such regulation would make tourism more respected profession, while tourism vocational schools would increase their visibility and improve their status in the society. The upgrade of 'dual education system' should improve the cooperation between high schools and tourism business entities. The practical contribution of this research is in providing empirically proved policy recommendations towards the improvement of vocational education for tourism in Croatia. At last, all these efforts should increase the employment of welleducated and highly skilled professionals in tourism, which would have a direct impact on customer satisfaction, market competitiveness, and business success.

This research has two major limitations that should be acknowledged. The first limitation is related to one-sided approach in which only teaching staff has been surveyed for the evaluation of the gap between tourism education outcomes and employment practice in Croatia. The second limitation of this research is in application of basic statistical methods due to a large quantity of data and the limited space for deeper analyses and discussions. The minor limitation is in relatively short period of primary data collection, limited to only several weeks. Future research endeavors in this field could consider examining teachers' perception of students' progress and VPTs learning outcomes, or the employability of students completed VPT and tourism employment trends. It would be also useful to extend this research on some other target groups, e.g. future and actual students, parents, curriculum developers and consultants, job providers, relevant state authorities, higher education institutions, employment mediation agencies, or professional associations in tourism, which have not been considered in this research. 
ToSEE - Tourism in Southern and Eastern Europe, Vol. 6, pp. 405-423, 2021.

O. Kesar, D. Ferjanić Hodak, E. Roginić: BRIDGING THE GAP BETWEEN TOURISM VOCATIONAL ...

\section{ACKNOWLEDGEMENTS}

The research presented in this paper is conducted within the framework of "ReCeZa" (UP.03.3.1.05.0001) project on regional centers of competence in tourism and hospitality in Croatia. The project is implemented within the Operational Program "Effective Human Resources 2014-2020", and is co-financed by the European Social Fund (ESF) and the Government of Croatia.

\section{REFERENCES}

Bartoluci, M. and Budimski, V. (2010), "Educational system of tourism experts in Croatia" (in Croatian), Hrvatski znanstveno stručni skup o menadžmentu u turizmu i sportu, Vol. 1, No, 1, pp. 7-19.

Baum. T. (2007), "Human resources in tourism: Still waiting for change", Tourism Management, Vol. 28, No. 6, pp. 1383-1399. doi: 10.1016/j.tourman.2007.04.005

Bečić, E. and Črnjar, K. (2009), "Trends on the tourism labour market", Tourism and Hospitality Management, Vol. 15, No. 2, pp. 205-216

Courage Shereni, N. (2019), "The Role of Technical and Vocational Education and Training (TVET) in Restoring Hospitality Sector Specific Skills in Zimbabwe: A Students' Perspective", Journal of Hospitality \& Tourism Education, Vol. 32, No. 3, pp. 133-141 doi: 10.1080/10963758.2019.1655434

CBS (2021a), Statistics in Line: Tourism, Croatian Bureau of Statistics, Zagreb, viewed 11 April 2021, https://www.dzs.hr/hrv/Publication/StatisticsInLine.htm

CBS (2021b), Statistics in Line: Employment and Wages, Croatian Bureau of Statistics, Zagreb, viewed 11 April 2021, https://www.dzs.hr/hrv/Publication/StatisticsInLine.htm

CBS (2020), Statistical Report: Tourism in 2019, No. 1661, Croatian Bureau of Statistics, Zagreb, viewed 11 April 2021, https://www.dzs.hr/Hrv_Eng/publication/2020/SI-1661.pdf

CBS (2019), Tourism Satellite Account for the Republic of Croatia, 2016, Croatian Bureau of Statistics, Zagreb, viewed 11 April 2021, https://www.dzs.hr/Hrv_Eng/publication/2018/12-04-01_01_2018.htm

Drexler, N. and Lapre, V. B. (2019), "For better or for worse: Shaping the hospitality industry through robotics and artificial intelligence", Research in Hospitality Management, Vol. 9, No. 2, pp. 117-120. doi: 10.1080/22243534.2019.1689701

Failte Ireland (2005). A human resource development strategy for Irish Tourism: Competing through People, 2005-2012, Dublin

Guskey, T. R. (2002), "Professional development and teacher change", Teachers and Teaching: Theory and Practice, Vol. 8. No. 3, pp. 381-391. doi: 10.1080/135406002100000512

Hidalgo-Peñate, A., Nieves, J. and Padrón-Robaina, V. (2020), “The influence of employees' knowledge, organisational commitment, and culture on the innovativeness of vocational educational", Knowledge Management Research \& Practice. doi: 10.1080/14778238.2020.1774431

Ladkin, A. (2005), Careers and employment. In: Airey, D. and Tribe J. (Eds.), An International Handbook of Tourism Education, pp. 437-450. UK: Elsevier.

Lee-Ross, D. and Pryce, J. (2010), Human Resources and Tourism: Skills, Culture and Industry, Channel View Publication, Bristol

Li,J.J., Bonn, M.A. and Ye, B.H. (2019), "Hotel employee's artificial intelligence and robotics awareness and its impact on turnover intention: The moderating roles of perceived organizational support and competitive psychological climate", Tourism Management, Vol. 73, pp. 172-181. doi: 10.1016/j.tourman.2019.02.006

Liu, A. and Wall, G. (2006), "Planning tourism employment: a developing country perspective", Tourism Management, Vol. 27, No. 1, pp. 159-170. doi: 10.1016/j.tourman.2004.08.004

Liu, H. and Xu, L. (2017), Development and Implication of Applied Tourism Higher Education in Germany, Advances in Economics, Business and Management Research, Vol. 23, pp. 150-153.

Lo, A. (2005), "The past, present, and future of hospitality and tourism higher education in Hong Kong”, in Hsu, C.H. (Ed.), Global tourism higher education: past, present, and future, The Haworth Hospitality Press, New York, pp. 137-166.

Mandić, A., Mrnjavac, Ž. and Koridć, L. (2018), “Tourism Infrastructure, Recreational Facilities and Tourism Development", Tourism and Hospitality Management, Vol. 24, No. 1, pp. 41-62. doi: 10.20867/thm.24.1.12 
ToSEE - Tourism in Southern and Eastern Europe, Vol. 6, pp. 405-423, 2021.

O. Kesar, D. Ferjanić Hodak, E. Roginić: BRIDGING THE GAP BETWEEN TOURISM VOCATIONAL ...

McCartney, G. and McCartney, A. (2020), "Rise of the machines: towards a conceptual service-robot research framework for the hospitality and tourism industry", International Journal of Contemporary Hospitality Management, Vol. 32, No. 12, pp. 3835-3851. doi: 10.1108/IJCHM-05-2020-0450

Moutinho, L. (2005), Strateški menadžment u turizmu, Masmedia, Zagreb.

MSE (2021), School e-Mine (in Croatian), Ministry of Science and Education of the Republic of Croatia Zagreb, viewed 15 April 2021 https://app.powerbi.com/view?r=eyJrIjoiZWE3YTE4OWQtOWJmNC00OTJmLWE2MjktYTQ5 MWJINDNIZDQ0IiwidCI6IjJjMTFjYmNjLWI3NjEtNDVkYi1hOWY1LTRhYzc3ZTk0ZTFkN CIsImMiOjh9

Nurhadi, D., Zahro, S. and Nyan-Myau, L. (2017), "A Retrospective on Educational Policies and Their Implementation in the Vocational Teacher Education Provision”, Croatian Journal of Education, Vol. 19, No.3, pp. 947-980. doi: 10.15516/cje.v19i3.2356

OECD, Dumont, H., Istance, D. and Benavides, F. (Eds.), (2010), The nature of learning: Using research to inspire practice, OECD Publishing, viewed 19 April 2021, https://read.oecdilibrary.org/education/the-nature-of-learning_9789264086487-en\#page1

Pavlić, I., Svilokos, T. and Šuman Tolić, M. (2015), “Tourism, Real Effective Exchange Rate and Economic Growth: Empirical Evidence for Croatia”, International Journal of Tourism Research, Vol. 17, pp 282-29. doi: 10.1002/jtr.1986

Perman, L. and Mikinac, K. (2014), "Effectiveness of Education Processes in Tourism and Hospitality in the Republic of Croatia”, in Perić, J. (Ed.), Tourism \& Hospitality Industry 2014: Trends in Tourism and Hospitality Industry, Proceedings of $22^{\text {nd }}$ Biennial International Congress, University of Rijeka, Faculty of Tourism \& Hospitality Management Opatija, pp. 616-630.

Peršić, M. (1998), "Training of Tourism Professionals in Croatia", World Leisure \& Recreation, Vol. 40, No. 3, pp. 19-25. doi: 10.1080/10261133.1998.9674115

Richards, G. (2003), "Tourism and Labour Mobility in the European Union", Tourism Recreation Research, Vol. 28, No. 1, pp. 77-86. doi: 10.1080/02508281.2003.11081388

Riley, M. and Szivas, E. (2009), "Tourism employment and poverty: revisiting the supply curve", Tourism Economics, Vol. 15, NO, 2., pp. 297-305. doi: 10.5367/000000009788254359

Silitonga, P. (2020), "Competency-based education: a multi-variable study of tourism vocational high school graduates", Journal of Teaching in Travel \& Tourism, Vol. 21, No. 1, pp. 72-90. doi: $10.1080 / 15313220.2020 .1820427$

Sobaih, A.E.E. (2015), "Hospitality Employment Issues in Developing Countries: The Case of Egypt", Journal of Human Resources in Hospitality \& Tourism, Vol. 14, No. 3, pp. 221-243. doi: 10.1080/15332845.2014.904167

Starc, J., Rodica, B. and Konda, I. (2015), "The significance of teaching methods/forms and organizational forms as important elements for the professional in the education and training of managers involved in tourism", Informatologia, Vol. 48, No. 1-2, pp. 48-61.

Šuligoj, M. (2017), "Warfare tourism: an opportunity for Croatia?”, Economic Research, Vol. 30, No. 1, pp. 439-452. doi: 10.1080/1331677X.2017.1305800

Tasci, A.D.A. and Knutson, B.J. (2004), "An Argument for Providing Authenticity and Familiarity in Tourism Destinations", Journal of Hospitality \& Leisure Marketing, Vol. 11, No. 1, pp. 85-109. doi: 10.1300/J150v11n01_06

Tomljenović, R. and Čorak, S. (2012), Proposals for the improvement of secondary education for the needs of tourism in Croatia [in Croatian], Institute for tourism, Zagreb.

Vizjak, A. and Vizjak, M. (2015), "Obrazovanje kao uvjet daljnjeg uspješnog razvoja turizma", Media, culture and public relations, Vol. 6, No. 2, pp. 196-204.

Wang, J. Ayres, H. and Huyton, J. (2010), "Is Tourism Education Meeting the Needs of the Tourism Industry? An Australian case study", Journal of Hospitality \& Tourism Education, Vol. 22, No. 1, pp. 8-14. doi: 10.1080/10963758.2010.10696964

WTTC (2020), Croatia 2020 annual research: key highlights, World Travel and Tourism Council, viewed 15 April 2021, https://wttc.org/Research/Economic-Impact

WTTC (2002), Building Human Capital, London: WTTC. 
ToSEE - Tourism in Southern and Eastern Europe, Vol. 6, pp. 405-423, 2021.

O. Kesar, D. Ferjanić Hodak, E. Roginić: BRIDGING THE GAP BETWEEN TOURISM VOCATIONAL ...

Oliver Kesar, PhD, Full Professor

University of Zagreb, Faculty of Economics \& Business Department of Tourism

Trg J. F. Kennedyja 6, 10000 Zagreb, Croatia

+385-1-2383-396

okesar@efzg.hr

Danijela Ferjanić Hodak, PhD, Associate Professor

University of Zagreb, Faculty of Economics \& Business Department of Tourism

Trg J. F. Kennedyja 6, 10000 Zagreb, Croatia

+385-1-2383-269

dferjanic@efzg.hr

Ema Roginić, MA, Project Associate Specialist

University of Zagreb, Faculty of Economics \& Business

Department of Tourism

Trg J. F. Kennedyja 6, 10000 Zagreb, Croatia

+385-1-2383-401

eroginic@efzg.hr 